\section{International entrepreneurship education for pre-service teachers: a longitudinal study}

Entrepreneur education for pre-service teachers

\author{
Didatics and Curriculum Development, Universidad de Deusto, \\ Bilbao, Spain, and \\ Jessica Paños-Castro \\ Universidad de Deusto, Bilbao, Spain
}

Arantza Arruti

\begin{abstract}
Purpose - The purpose of this paper is to explore whether participating in an entrepreneurship education programme with short-term international placements can help pre-service teachers to identifying the characteristics of entrepreneurial competence from a wide definition of entrepreneurship (Lackéus, 2015) rather than from a business centred definition, to be developed by entrepreneur teachers.

Design/methodology/approach - A three-year longitudinal qualitative study was carried out. In-depth interviews were conducted using open-ended questions with 17 pre-service teachers from the University of Deusto (Spain). They were participating in a European project with short-term international placements at five different European higher education institutions.

Findings - There is no consensual definition of the term entrepreneurship, which varies depending on the context. Entrepreneurship could be considered to be both a mindset and a lifestyle. The characteristics of entrepreneurs that were mentioned the most included: being creative, team players, open-minded, innovative, passionate, motivated, hard-working and risk-takers; being able to overcome challenges; having initiative; being proactive, organised and persevering; having leadership skills, communication skills, the ability to adapt; having a positive attitude and, being decision-makers. Short-term placements contribute to personal development, improved foreign language competence, increased awareness and understanding of other cultures, and acquiring entrepreneurship competence.

Originality/value - Research on the characteristics of teacherpreneurs is still in its early stages. The vast majority of studies focus on entrepreneurs and teachers of entrepreneurship education programmes aimed at those who wish to start up new businesses. This study contributes to a better understanding of the term entrepreneurship, to identifying the current characteristics of teacherpreneurs, and to outline certain variables that could be considered during pre-service teachers training plans. It also proposes further research into in-service teacherpreneur education.
\end{abstract}

Keywords Higher education, Primary school teacher, Entrepreneurs, Entrepreneurship, Teacher training, Entrepreneurship education

Paper type Research paper

\section{Introduction}

The European Commission first noted the importance of entrepreneurship education (EE) in the Green Paper on Entrepreneurship in Europe (Commission of the European Communities, 2003). As it will be stated later, we understand EE as a key competence for pre-service teachers, which development will contribute to their personal and professional fulfilment as facilitators of the comprehensive training of active citizens, especially children, during their

(c) Arantza Arruti and Jessica Paños-Castro. Published by Emerald Publishing Limited. This article is published under the Creative Commons Attribution (CC BY 4.0) licence. Anyone may reproduce, distribute, translate and create derivative works of this article (for both commercial and non-commercial purposes), subject to full attribution to the original publication and authors. The full terms of this licence

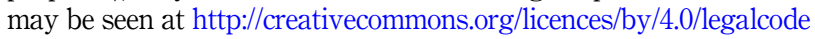

Received 27 April 2020

Revised 17 July 2020 29 July 2020

Accepted 10 August 2020 
primary education. Since the Green Paper, multiple plans, several actions, a great variety of papers and research (Henry and Lewis, 2018), and numerous commissions have been carried out in this area. Many of them, if not all, have stressed the importance of entrepreneurship, EE, and the need for it to be continuously promoted and encouraged in every sphere of life. It is considered an important element in achieving economic, social and sustainable development (Bacigalupo et al., 2016; Hameed and Irfan, 2019; Isa, 2019; Sadewo, 2020; Sam and van der Sijde, 2014; Saravia and Paiva, 2020; Von Graevenitz et al., 2010), and also a key aspect in fostering creativity and innovation (Boldureanu et al., 2020; Welsh et al., 2016).

This may be one of the reasons why some authors have stated that universities need to become more entrepreneurial (Comisión Europea, 2013; Gibb et al., 2013; Taatila, 2010). It has also been argued that, in addition to focussing on promoting entrepreneurship, universities must "promote entrepreneurship on teaching and research" (Paiva et al., 2019, p. 154). As Aparicio et al. concluded (2019, p. 105), "EE research has evolved from EE as part of an economic development strategy to the EE academic perspective".

Although EE and training have grown rapidly in recent decades, in most countries the provision of $\mathrm{EE}$ in formal training is still inadequate (Coduras et al., 2010). The European Commission advised that "it clearly seems that some efforts could be made to improve both the initial education of teachers and the provision of continuing professional development courses for entrepreneurship education" (European Commission/EACEA/Eurydice, 2016, p. 14), and whereas some authors have reported that the teaching of entrepreneurship and entrepreneurial education courses and programmes have not been sufficiently incorporated into the higher education curricula (Wibowo et al., 2018).

Specifically, as regards pre-service or initial teacher education and training, "only seven education systems treat entrepreneurship education as a compulsory topic in initial education for teachers, at least for some prospective teachers" (European Commission/ EACEA/Eurydice, 2016, p. 94) but it seems that even today, EE at the university level is deficient and is generally found in business disciplines (Neck and Greene, 2011; Suska, 2018).

The Council of the European Union (2006, pp. 1-2) claimed that "entrepreneurship requires the gradual development of a range of competences, starting from an early age [...] addressed at all levels of education and training [...] teachers, trainers and educational leaders should be encouraged to foster entrepreneurial skills, competences and mindsets". This could help teachers also to develop and implement an entrepreneurial attitude amongst their students from an early age.

After a systematic review of EE in higher education institutions, Othman and Othman (2019, p. 2413) concluded that "the curriculum developed by the institution must be in line with the outcome of entrepreneurship education". In this vein, some studies have shown that "university-level entrepreneurship education is of critical importance in fostering entrepreneurial intentions and attitudes among undergraduate and postgraduate students" (Yomi-Akinola and Adedapo, 2019), whereas Zhao (2019, p. 1380) pointed out that EE should be considered a "key content in the reform and development of university education and teaching."

It would be necessary to rethink the educational models of initial teacher training to ensure that they can adapt to the new demands of the Information and Communication Society (Rodríguez-Martínez and Díez, 2014). Furthermore, educational policies should ideally reflect this. As Saraiva and Paiva (2020) stated, the European Union, the Organisation for Economic Co-operation and Development (OECD) and the United Nations seem to have largely adopted entrepreneurship as a tool to develop public policies aimed at achieving certain social, environmental, economic and even cultural objectives. It can be said that EE is not only a European issue but also international. In fact, the United Nations Conference of Trade and Development (UNCTAD), a permanent intergovernmental body established by the United 
Nations General Assembly, stressed its importance. Amongst the recommended actions, this body proposed to embed entrepreneurship in formal education through the development of entrepreneurship awareness and behaviours starting from primary school level; and regarding teacher training, to encourage entrepreneurship training for teachers and promote entrepreneurship educators' networks. The aim of the UNCTAD is to develop an entrepreneurial culture through the development of soft skills such as persistence, networking and self-confidence, complemented by "creativity and a sense of initiative; problem solving and critical thinking; decision-making and risk taking; adaptability and perseverance; selfdiscipline and a sense of responsibility; leadership and teamwork; planning and organisational ability; understanding of the social, economic and cultural context; and language skills and the ability to persuade" (Council of the European Union, 2015, p. 1).

\section{Entrepreneurship}

There is no consensual definition of entrepreneurship. It is a term that is used in multiple ways today, either by itself or in combination with other terms (entrepreneurial initiative, initiative and entrepreneurship, entrepreneurship spirit and entrepreneurship competence, amongst others).

Bridge (2017) stated that there are many very different ways of interpreting the term entrepreneurship, and that one must distinguish between entrepreneurship as enterprise for life and entrepreneurship as enterprise for new venture creation (Bridge, 2017). It is an umbrella term that continues to be applied to a wide variety of programmes, as no general agreement seems to exist on how to define it despite more than 60 years of research on the topic and "it is not immediately clear what meaning is intended in any particular case to which the word entrepreneurship is applied" (Bridge, 2017, p. 741). Bridge identified two major consequences of this lack of definition and consensus, namely, "an inappropriate borrowing of course content, and a lack of clarity about aims".

In the case of the OECD, considering from a wide definition, entrepreneurship has to do with personal development, creativity, self-reliance, initiative taking and action orientation (Lackéus, 2015). Those are some of the competences that pre-service teachers should develop in order to help students to apply their knowledge and competences "in unknown and evolving circumstances" (OECD, 2018, p. 5).

Apart from that, as Lackéus (2015, p. 6) posited, permeating entrepreneurship into education posed positive effects but also some challenged encountered by teachers such as "lack of time and resources, teachers' fear of commercialism, impeding educational structures, assessment difficulties and lack of definitional clarity" concerning competences to be developed and the way to do it. This study tries to contribute to the decision of the main competences of teacherpreneurs.

In the case of de Pablo et al. (2019), entrepreneurship is linked to initiative and action, and to individuals with an entrepreneurial spirit who possess the capacity to innovate. For them, entrepreneurship is an active field and helps develop "attributes such as the capacity for transformational change, the ability to experiment with their own ideas and the capacity to be flexible and react quickly [. . . ] involves developing both personal attributes and social values, characterized by responsibility, commitment, endeavour, dedication, perseverance and a strong work ethic" (de Pablo et al., 2019, p. 1).

This is the discourse adopted by Welsh et al. (2016) when they held that EE must help people to develop "the right attitudes, motives, intentions, and grit to meet failure with a determination to start over again and win”. (p. 131). As Gómez et al. (2017) stated, the entrepreneurship competence involves the interaction of the individual with their environment, as well as some "attitudes (learning how to be, that is, an attitudinal dimension), skills (learning how to do, that is, a procedural dimension) and knowledge
Entrepreneur education for pre-service teachers 
(learning how to know, that is, a dimension of knowledge) conducive to evaluating , generating and sustaining initiatives in different situations" (p. 158).

The European Parliament, for its part, defined the initiative and entrepreneurship competence as the "individual's ability to turn ideas into action. It includes creativity, innovation and risk-taking, as well as the ability to plan and manage projects in order to achieve objectives [..] should include awareness of ethical values and promote good governance" (The European Parliament and the Council of the European Union, 2006, p. 17). In fact, this is the definition adopted for this study, together with that of EE and the characteristics of entrepreneurs, which will serve to close the circle.

\section{Entrepreneurship education}

San-Martín et al. (2020) stated that there is no single way to define EE, as there are many ways to conceptualise it. Welsh et al. (2016) pointed out that teaching EE involves teaching how to apply flexibility, adaptability and resilience in order to adapt and respond to changes in workforce demands over time. According to Paiva et al. (2019, p. 152), "the scope and focus of entrepreneurship education vary according to the types of institutions and years of experience in entrepreneurship education." Moreover, it seems that the change in how entrepreneurship is conceived will have consequences for EE.

Bearing in mind the multiple definitions and understandings of $\mathrm{EE}$, this study has adopted the definition used by the European Commission/EACEA/Eurydice (2016). EE is understood as a key competence for students (including pre-service teachers) whose development, as well as that of the series of sub-competences that comprise it, will contribute to their personal and professional development as active citizens in a society in constant change; specifically, as facilitators of the comprehensive training of these citizens, especially children during their primary education. The next section will discuss this in more detail.

According to Ragil et al. (2019), entrepreneurship competence is needed and needs to be promoted amongst pre-service teachers, especially primary education teachers, with a view to enhancing the development of this competence in primary schools. In this vein, Galvão et al. (2018) emphasised the positive impact of EE on knowledge enhancement, self-confidence and skill development. Akudolu (2010), cited by Isa (2019, p. 67), viewed EE “as the acquisition of knowledge, skills and attitude to enable the learner apprehend life challenges in whatever form and take decisive steps to realize new trends and opportunities for meeting those challenges in all aspects of human life". Similarly, Tan and $\mathrm{Ng}$ (2006), as quoted in Hameed and Irfan (2019, p. 5), defined EE as "a process where individuals are provided with the basic concepts and skills about how to identify opportunities and how to find out the solutions where other people vacillated".

As Blass (2018) noted, it is not that entrepreneurs have a business curriculum, but rather a curriculum that helps them find themselves, know what they want and develop tolerance for failure, resilience and emotional intelligence. This is perfectly aligned with the ideas listed by Zangeneh et al. (2020), who stressed the special role of teachers in EE when they show a good attitude and entrepreneurial insight. In this way, they can foster the development of creative people and their entrepreneurial spirit. These authors considered teachers to be one of the most important factors in EE.

The European Commission (Comisión Europea, 2008, 2014) highlighted that new teachers must be made aware of the need for EE, as they would be better able to inspire their students than those who are not aware. Ferreiro (2011) also noted that, if the person in charge of developing students' key competences and shaping their learning processes does not possess these attributes, it will be very difficult for them to help students develop them.

Finally, the research done by Lackéus (2015) concluded that EE is "largely disconnected from the educational domain, and offers little advice to teachers [...] There is a need for 
robust advice on what to let students do in order to develop their entrepreneurial competencies" (p. 26). In this respect, the Danish Foundation for Entrepreneurship - Young Enterprise identified (Rasmussen and Nybye, 2013) four basic dimensions that educators, regardless of educational level, need to take into account and that are embedded in the curriculum of the school and the educational institution, depending on the educational level and field: action (to implement value creating through cooperation, networking and partnerships, to communicate, to organise, specify, plan and lead activities, and to analyse and handle risk), creativity (to discover and create ideas and opportunities, to combine knowledge, experience and personal resources, to create and revise personal perceptions, and to experiment and solve problems and meet challenges), environment (to analyse a context socially, culturally and economically as a setting for value-creating actions and activities) and attitudes (belief in one's own ability to act, ability to work consistently and overcome ambiguity, uncertainty and complexity, to accept and learn from others' and own failures , and to make ethical evaluations and reflections).

\section{Characteristics of entrepreneurs}

While there are many studies concerning the characteristics of entrepreneurs, there is no consensus regarding the type and number of traits that define them.

Taking into account recent research, Hameed and Irfan (2019) pointed out seven characteristics that can be associated with entrepreneurs: innovativeness, need for achievement, locus of control, propensity for risk-taking, having a positive attitude, motivation and fortitude. Syae (2020), for his part, identified the following entrepreneurship values: honesty, discipline, hard work, creativity, being innovative, independent, responsible, easy to work in a team, leadership skills, tenacious, willing to take risks, being committed, realistic, curiosity and appreciating communicative accomplishments.

Gomez et al. (2017), attempted to operationalise the components of entrepreneurial competence by identifying the following attitudes and skills: proactivity, risk-taking, creativity, self-awareness, self-efficacy, self-confidence, tolerance to uncertainty, ambiguity and frustration, and perseverance (attitudes), and problem-solving, exploring opportunities, communication, planning and teamworking (skills). In the case of López et al. (2019), they identified more than 30 teachers' aims when developing educational entrepreneurship programmes.

The characteristics of entrepreneurial teachers or teacherpreneurs have been identified by the authors elsewhere (Arruti and Paños-Castro, 2020). Teacherpreneurs are professionals who are passionate about teaching, have a positive attitude and a great ability to inspire others, as listed in Table 1. Finally, a study recently carried out by Keyhani and Kim (2020) based on a systematic literature review of teacher entrepreneurship should also be borne in mind. In an attempt to conceptualise the term, they concluded that entrepreneurial teachers are socially motivated, innovative, collaborative, proactive, opportunity-minded, fully present in their work, knowledgeable, dedicated, resourceful, risk tolerant, visionary and self-improvement oriented.

\section{Methodology}

This study is part of the KA 203-Strategic Partnerships for higher education included in Key Action 2 of the ERASMUS + programme: Cooperation for innovation and the exchange of good practices, reference number 2017-1-DE01-KA203-003582. This project is called Entrepreneurship in Initial Primary Teacher Education (EIPTE).

Eight institutions belonging to six different countries participated in this strategic action: University of Deusto (Spain), Artesis Plantijn Hogeschool Antwerpen (Belgium), Fonden for
Entrepreneur education for pre-service teachers 
ET

$62,7 / 8$

\section{0}

Table 1.

Competences of teacherpreneurs
Entrepreneurial

Organisational

Communication

Intrapersonal

\author{
Entrepreneurial
}

Social

Note(s): Developed by the authors
(1) Self-motivation

(2) Self-confidence

(3) Self-efficacy

(4) Commitment

(5) Tenacity

(6) Perseverance

(7) Sense of responsibility

(8) High internal locus of control

(1) Ability to act on their own initiative

(2) Ability to be autonomous

(3) Having an entrepreneurial spirit

(4) Creativity

(5) Innovation

(6) Leadership skills

(7) High tolerance for uncertainty

(8) Risk-taking ability

(1) Ability to adapt to the environment

(2) Being flexible and adaptable to change

(3) Open-mindedness

(4) Project management skills

(5) Ability to use active, innovative methodologies

(6) Decision-making skills

(1) Verbal and written communication skills

(2) Digital skills

(1) Ability to work in a team

Entreprenørskab (Denmark), Leuphana University of Lüneburg (Germany), Mid Sweden University (Sweden), Technichus Science Center (Sweden), University College Absalon (Denmark) and University of Applied Sciences, Vilniaus Kolegija (Lithuania). These institutions worked together from August 2017 until August 2020 in order to achieve a common objective: increasing the number of higher education institutions that carried out entrepreneurial education and/or to improve the quality of EE programmes in the initial training of primary school teachers. Two hundred students participated in the programme which involved five intensive learning weeks.

A three-year longitudinal qualitative study was carried out. The same sample was used from September 2017 to March 2020. The methodology involved asking open-ended questions during closed interviews. This provided access to the views held by the same subjects on the topic over a timeline.

The sample was made up of 17 students from the Primary Education Degree at the University of Deusto (Spain) who participated in the EIPTE project. These were all the Spanish participants in the project, three of whom were men $(17.6 \%)$ and 14 of whom were women $(82.4 \%)$.

The interviews were carried out at five different points in time, after the students had participated in each of the Intensive Week for Learners (IWL) (short-term international placement) held at the University College Absalon (Denmark), Artesis Plantijn Hogeschool Antwerpen (Belgium), University of Deusto (Spain), Mid Sweden University (Sweden), and University of Applied Sciences, Vilniaus Kolegija (Lithuania), respectively. The first set of interviews were conducted in May 2018, the second set in December 2018, the third set in April 2019, the fourth set in December 2019 and the last set in March 2020.

Around 100 pre-service teachers from the different institutions participated during the different IWL, an average of 75 students each week. They shared knowledge, experiences, emotions, thoughts and similar. 
Before starting the interviews, all the participants were informed of the objective of the study, and they were assured that their participation would be confidential and anonymous.

The questions were posed to the students at the end of each intensive week.

Throughout the longitudinal study, the first two questions were always the same:

(1) What do you understand by entrepreneurship?

(2) What are the main characteristics of an entrepreneur?

However, the question "Do you think that your educational experience during the intensive programmes has had an impact on your entrepreneurial spirit?" was asked once they had participated in more than one IWL. The question "After taking part in this project, why do you think it was worth participating?" was asked after their participation in the final IWL in order to learn about the benefits of the Erasmus + project.

All the interviews were transcribed verbatim, without making judgements. Then they were coded, and the data were analysed. More than one interviewer was involved in the process, with the aim of reducing the sources of bias and ensuring greater reliability.

The general objective of the study was to test whether participation in an EE programme with short-term international placements could help pre-service teachers identify the characteristics of entrepreneurial competence, entrepreneurs and entrepreneurial spirit.

The fact of using open-ended questions was to obtain a greater amount of information, involving the thoughts, emotions and ideas expressed in the students' own words (Bisquerra, 2009).

\section{Results}

After the first intensive week, a variety of definitions were given for the first question (What do you understand by entrepreneurship?), and there was no unanimous consensus. For some participants, entrepreneurship was a way of thinking, an action, an attitude towards life, a way of doing things differently, of being able to make an innovative idea real, and a process in which ideas and concepts become actions and products. The definitions included concepts such as taking risks to achieve a goal, creativity, innovation, change, new things and teamwork.

The characteristics of an entrepreneur that were mentioned the most by respondents during their interviews were creativity, teamwork, hard work and open-mindedness. In particular, the participants argued that any entrepreneurial project requires working with other people and, therefore, patience, respect for the ideas and opinions of others, adaptability and flexibility, empathy and active listening are required. Table 2 presents the characteristics that were mentioned the most by the participants. On average, the participants provided five characteristics.

After the second IWL held in Belgium, three questions were asked instead of two, as stated in the methodology section. No unanimous answers were found to the first question relating to the definition of entrepreneurship. The participants defined entrepreneurship as: a new way of teaching and thinking, trying out different things, the ability to carry out something (whether a project or an activity), a competence, a way of changing things, a means for solving problems, a way of turning their ideas into reality, an action which involves risktaking and the ability to transform standard ideas into innovative ideas. They added that entrepreneurship is innate, and everyone is born with it. One participant argued that entrepreneurship would help them break away from traditional teaching-learning methods. Most of the subjects used the concepts of teamwork, creativity, innovation, risk-taking, planning, willingness to changing the world and willingness to be useful in their definitions.

In the second IWL, the participants named fewer entrepreneurial characteristics; specifically, an average of 4.05 . The characteristics that were mentioned most often were
Entrepreneur education for pre-service teachers 
ET

$62,7 / 8$

\section{2}

creativity, risk-taking, teamwork and innovation. Table 3 itemises the characteristics that were mentioned most often.

All participants answered the third question ("Do you think that your educational experience during the intensive programmes has had an impact on your entrepreneurial spirit?") in the affirmative. More than half of the participants reported that the experience had helped them to define the word entrepreneurship; develop, grow and put their entrepreneurial skills into practice; and exchange ideas and experiences with other people. For three students this experience was "an excellent opportunity to learn how to apply entrepreneurial skills to teaching children and has changed my mind in order to not to teach in a theoretical way" (Student 2). A participant pointed out that entrepreneurship is not linked to the business world.

The third intensive learning week took place in Spain. The responses to question one after this experience were more diverse. Four students thought that entrepreneurship was the ability to start or carry out something new. That could be "to start a new project, idea or an innovative product". Four students also thought that it was a new way of teaching, doing things, thinking or changing something. Two participants linked the definition to the education area. They indicated that it is necessary to adapt theoretical knowledge and use an active methodology. The rest of participants connected it with a competence "that encompasses a whole set of skills such as creativity, leadership, teamwork, innovation and decision making" (Student 5). The answer given by one of the participants highlighted the context where entrepreneurship occurs: "many people believe that entrepreneurship is centred on the creation of companies or economic profits, thus forgetting the social part, which I believe is essential" (Student 5).

The participants listed a range of characteristics, which placed the arithmetic mean of the answer at 6.8. On this occasion, the characteristics that were most often mentioned were creativity, innovation, teamwork, open-mindedness, passion and risk-taking (see Table 4).

Regarding this third question, one student classified the characteristics of entrepreneurs into four groups: personal development, philosophical and ethical competences, social skills

\begin{tabular}{lclc}
\hline Characteristics & Times mentioned & Characteristics & Times mentioned \\
\hline Creativity & 10 & Risk-taking & 2 \\
Teamwork & 8 & Good planning skills & 2 \\
Hard work & 6 & Belief in one's dreams & 2 \\
Open-mindedness & 6 & Organisation skills & 2 \\
Innovation & 4 & Self-efficacy & 2 \\
Patience & 3 & Perseverance & 2 \\
Motivation & 3 & Empathy & 2 \\
Bravery & 3 & Capacity for active listening & 2 \\
Passion here we need to be consistent & 2 & Good communication skills & 2 \\
Positive attitude & 2 & Having clear ideas & 2 \\
\hline
\end{tabular}

Table 2.

Most mentioned entrepreneurial characteristics after the first IWL

\begin{tabular}{lclc}
\hline Characteristics & Times mentioned & Characteristics & Times mentioned \\
\hline Creativity & 7 & Passion & 2 \\
Risk-taking & 4 & Motivation & 2 \\
Teamwork & 4 & Leadership skills & 2 \\
Innovation & 4 & Initiative & 2 \\
Open-mindedness & 3 & Willingness to engage in ongoing learning & 2 \\
Hard work & 3 & Good organisation skills & 2 \\
\hline
\end{tabular}


and work-related skills. Another participant noted that "an entrepreneur has no specific characteristics but a little bit of everything" (student 11). All the participants indicated that the intensive programme had had an impact on their entrepreneurial spirit. For two students, this experience helped them to understand what entrepreneurship was. For most participants (specifically, six of them) this programme was apprenticeship training for their future job: "I think this will be useful in my future, and will make a difference in my practice as an entrepreneur or teacherpreneur" (student 15). The reasoning was that they had learnt a "lot of techniques, methods, new methodologies, tools and resources such as visual thinking and design thinking" (student 3). The rest of the participants indicated that it was useful to grow as an entrepreneur and teacherpreneur, to put into practice some of the entrepreneurial characteristics, and to become more committed to education and the environment.

After the fourth intensive week, participants were asked the first three questions again. This time they defined entrepreneurship in different ways. They were aware of the fact that "entrepreneurship is more complex than we imagine" (student 13). Two students admitted that "even though everybody thinks it is only focused on the economic field, entrepreneurship appears in many other fields, like education" (student 17), and also, "it isn't only centred in the creation of companies or economic profits, but also in a social environment" (student 5). For most participants, entrepreneurship is "a positive attitude in order to achieve something big that makes a person think out of the box and take risks. For example, change your methodology until find the best one" (student 17). For others, entrepreneurship is an action to improve, transform, change or create something new. For example, "transform standard ideas into an innovative idea" (student 12), "improve something in society" (student 16 and 14) and "change traditional education" (student 11).

One participant thought that "it is a competence or skill that encompasses a whole set of skills" such us risk-taking, teamwork, motivation, creativity, innovation, open-mindedness and learning by doing (student 5). In this area, "it is important to evaluate the environment where entrepreneurship takes place, because an entrepreneur creates an ecosystem" (student 5). This time participants listed an average of 5.5 characteristics. The ones that were mentioned the most were creativity, teamwork, innovation, open-mindedness and motivation (see Table 5). Different interrelated concepts were named by participants at this point. For example, creativity and imagination, teamwork and networking, being a hard worker and working proactively. Again, one of the students classified entrepreneurial skills into personal development, philosophical and ethical competencies, social skills and work-related skills.

In the last question, all respondents but one reported that the training programme had enhanced their entrepreneurial spirit. Six students believed that they had learnt several new techniques, methodologies and strategies to be applied in their future lessons, including visual thinking and value creation learning. This made "a noticeable difference in teaching"

\begin{tabular}{lclc}
\hline Characteristics & Times mentioned & Characteristics & Times mentioned \\
\hline Creativity & 11 & Motivation & 3 \\
Innovation & 10 & Communication skills & 2 \\
Teamwork & 7 & Risk management & 2 \\
Passion & 6 & Decision-making skills & 2 \\
Open-mindedness & 6 & Ability to deal with emotions & 2 \\
Risk-taking & 5 & Respect & 2 \\
Initiative & 4 & Self-confidence & 2 \\
Hard work & 4 & Positivism & 2 \\
Flexibility & 3 & Social involvement & 2 \\
Organisation skills & 3 & Adaptability & 2 \\
Perseverance & 3 & Capacity for active listening & 2 \\
\end{tabular}

Entrepreneur education for pre-service teachers

833

\footnotetext{
Table 4.

Entrepreneurial characteristics that were most often mentioned after the third IWL
} 
ET

$62,7 / 8$

834

and "could change education and society for the better" (student 17). Another two participants felt more entrepreneurial and believed that they had put into practice some entrepreneurial characteristics such as creativity, teamwork and innovation. Two students also "began to have a huge motivation to learn more about entrepreneurial learning" and they "wanted to become a teacherpreneur" (student 16).

The last IWL took place in March 2020 and participants were asked four questions. This time, five students indicated that the context was not only related to business: "At first, I couldn't connect entrepreneurship with the educational world" (student 4); "it is not only linked to the business world; you can support an entrepreneurial spirit in any field" (student 7); "the concept of entrepreneurship is based on an economic context. However, like all concepts, it evolves and becomes understood in different ways as society develops and grows (student 3); "entrepreneurship can be used in many fields, like education, but we must stop thinking that it is only linked to economics" (student 17); "when we started this project, the concept was linked to business in our minds, and it is still linked to it in people's minds. Now we understand that entrepreneurship goes much further. (...) It is a spirit or a lifestyle" (student 10). To sum up, "anyone can be entrepreneurial in any activity" (student 10).

Five students thought that entrepreneurship is a way of living, thinking, acting and doing things differently. Another definition given was connected with creativity: "It is to create something new or something that already exists from an idea, in order to improve society somehow" (student 17); "any creation of value for society, our environment, or even for our planet" (student 5); "building something different" (student 12). Two students defined it as an action and transformation of a process, idea or project. They also thought that it involved risk, innovation, motivation and passion. Finally, an average of 6.9 characteristics were given by students to answer the second question. The characteristics that were most often mentioned were creativity, teamwork, open-mindedness, passion, motivation and innovation (see Table 6). Nevertheless, some concepts were not linked to characteristics. For example, methodologies and activity. If these answers are compared to the ones given after participating in the first intensive week, there are new terms such as willingness to explore, humility, enthusiasm and the ability to inspire others.

As far as question three is concerned, everyone affirmed that the experience in Lithuania had had an impact on their entrepreneurial spirit. The vast majority stated that they had learnt different techniques, innovative methodologies, strategies and laws that helped them not to do things in the same way, and to take the opportunity to change the education system. They believed that this could be implemented in their future lessons when they become teachers, and it will help them be more competent. They specifically referred to their learning of STEAM (Science, Technology, Engineering, Arts and Math), visual thinking, Nordic education, ecosystem of entrepreneurship and sustainable development goals.

The participants emphasised that they had grown professionally and personally and that this would help them become better teachers and improve their self-knowledge. For four

Table 5.

Entrepreneurial characteristics that were most often mentioned after the fourth IWL

\begin{tabular}{lclc}
\hline Characteristics & Times mentioned & Characteristics & Times mentioned \\
\hline Creativity & 8 & Passion & 2 \\
Teamwork & 7 & Ability to be resourceful & 2 \\
Innovation & 7 & Good organisation skills & 2 \\
Open-mindedness & 5 & Proactivity & 2 \\
Motivation & 5 & Good communication skills & 2 \\
Passion & 4 & Positive attitude & 2 \\
Leadership skills & 4 & Ability to adapt & 2 \\
Hard work & 3 & Risk-taking & 2 \\
Initiative & 2 & & \\
\hline
\end{tabular}


students, the training programme had helped them stimulate their entrepreneurial skills in terms of creativity, curiosity, self-confidence, exploring ideas, solving problems, dealing with challenges and how to work with other people. One of the students stated: "I believe that I have been an entrepreneur person from the beginning, but thanks to this project I have been able to grow and make my knowledge more meaningful" (student 13). This shows that there were students who were willing to keep on learning more about being a teacherpreneur.

At this point, it is important to highlight three ideas mentioned by the respondents. Firstly, they repeatedly mentioned that the term entrepreneurship is not only linked to the economic field. Secondly, they recognised that Spanish students are good teacherpreneurs. And lastly, they had a clear idea of what entrepreneurship is. In short, the participants stated that being in contact with students of other nationalities was a unique, rewarding experience, which was very useful to them, as they could exchange ideas, continue learning and get to know people with different ideas.

Regarding the fourth question, all the participants valued the project very highly. While in the beginning their experience was not that positive, in the end they felt proud to have taken part: "At first I preferred spending my time doing my own work or staying in my country with my people"; "at first I did not understand the meaning of entrepreneurship" (student 3); "when starting the project many people, including myself, did not know what entrepreneurship was" (student 12).

To sum up, students stressed three ideas. Firstly, that the short-term international placement was a unique opportunity to visit other countries; work and share ideas with other people of different nationalities, get to know other cultures and somehow create a new "family". Secondly, that they acquired new skills such as teamwork, creativity, empathy, socialisation and decision-making skills. And thirdly, they thought that the training programme suitably complemented their degree in primary education, and that they would like to continue learning about entrepreneurship.

There is no doubt that in the case of Spanish students, there have been a clear positive evolution regarding the knowledge about the teacherpreneur, his competences and characteristics, as well as the training and implementation of active methodologies and techniques. This may be due not only to their participation in the IWL but also to the fact that they were still following their studies at university and, moreover, doing their internships before finishing them.

\section{Discussion}

As the literature has noted, there is no consensual definition of entrepreneurship today, and definitions may vary depending on the context and approach adopted (Bridge, 2017; de Pablo et al., 2019; Núñez and Núñez, 2016). Basically, this term has two meanings, namely, the

\begin{tabular}{lclc}
\hline Characteristics & Times mentioned & Characteristics & Times mentioned \\
\hline Creativity & 9 & Initiative & 2 \\
Teamwork & 7 & Responsibility & 3 \\
Open-mindedness & 6 & Ability to overcome adversity & 2 \\
Passion & 6 & Perseverance & 2 \\
Motivation & 5 & Patience & 2 \\
Innovation & 5 & Willingness to learn & 2 \\
Hard work & 4 & Organisation skills & 2 \\
Risk-taking & 4 & Dynamic attitude & 2 \\
Leadership & 3 & Hope & 2 \\
Decision-making skills & 3 & &
\end{tabular}

Entrepreneur education for pre-service teachers

835 
creation of a company and/or business, and a useful key competence in any professional and personal sphere. What seems increasingly clear is that an entrepreneur is not the same as a business person, although many use the terms interchangeably, as synonyms (Bucardo et al., 2015). As reported by the participants in the study, "entrepreneurship is outside the business world" (student 2); "I understand that entrepreneurship goes much further. It is not a concrete project or a specialty for business degrees, it is a spirit or a lifestyle. Anyone can be entrepreneurial in any activity done during the day: cooking, doing exercise, doing homework and, of course, working" (student 10), etc. Despite this, some students found it very difficult to define it, and used phrases such as "it is something...". And yet, an increasing number of participants touched on the concept of entrepreneurship for life coined by Bridge (2017).

Similarly, as Hattie (2003) and Berry et al. (2007) stated, entrepreneurship is a concept that is not only limited to the business and economic field, and EE is a perfect ally for the training of future teacherpreneurs as a driver of change and a first-rate innovative partner-agent.

\section{Conclusion}

Considering the characteristics of entrepreneurs, it could be concluded that the students were not misdirected, since there are a large number of studies on the characteristics of entrepreneurs, but none has been able to validate the characteristics of a successful entrepreneur (Bucardo et al., 2015), successfully conceptualised the term teacherpreneur (Keyhani and Kim, 2020), or determined the basic skills of the teacherpreneur.

The characteristics that were most often mentioned by respondents during their interviews and after participating in each of the IWLs were creativity, teamwork, openmindedness, innovation and passion, in line with authors such as Keyhani and Kim (2020); Raine and Pandya (2019) and Syae (2020). The characteristics that the participants repeated every time they were asked, in addition to the previous ones, included motivation, hard work, risk-taking, ability to deal with challenges, taking the initiative, proactivity, organisation skills, perseverance, and leadership and communication skills, as well as an ability to adapt, be positive and make decisions. This group of characteristics, to a greater or lesser extent, have also been identified by the European Parliament (The European Parliament and the Council of the European Union, 2006); Coduras et al. (2016); Gomez et al. (2017); Keyhani and Kim (2020) and López et al. (2019).

It is also worth highlighting some of the characteristics listed at least once by the respondents and by Keyhani and $\operatorname{Kim}$ (2020) in their recent study. These include willingness to engage in ongoing learning, ability to engage socially, ability to be resourceful, a sense of responsibilityand self-confidence.

IWLs or short-stay international placements allowed students to integrate current concepts into their responses, such as the Sustainable Development Goals, ecosystem, creating a better world, self-efficacy, visual thinking and design thinking.

Participation in this project also contributed to achieving some of the objectives that the European Commission (2020) promotes through the Erasmus + programmes.

This is something that the study's participants also noted: "those intensive weeks complement the training at the University" (student 11), "I definitely recommend all Primary education students to participate if they have the opportunity" (student 7); "It is great to see that some teachers from our university work hard in order to create this type of projects to work on a topic that it is not taught as a subject and we do not have enough time to study it in depth" (student 17). This illustrates how they have been acquiring skills and enhancing their attitudes by learning over time (Rodríguez, 2016).

\section{Research implications}

We advocate for a form of $\mathrm{EE}$ that is open to the outside world; that uses and allows students to apply their own resources; that provides added value to themselves and to others; that 
encourages students to become more active, determined, motivated and self-effective and that uses learning methodologies in which creativity, openness and problem-solving are essential (Linton and Klinton, 2019; Ruiz et al., 2019).

We also believe that as Keyhani and Kim (2020) declared, the competences of the teacherpreneur "can be developed in teacher education programmes for preservice teachers or in professional development opportunities provided to current teachers" (p. 14). This could be one of the main challenges but also contributions of this study.

In fact, through this research the authors want to stress the need to renew teacher training curriculum. It could be done taking into account the main competences to be developed amongst primary education pre-service teachers resulted from this study, such as teamwork, creativity, decision-making skills, motivation, innovation, perseverance, taking the initiative and risk-taking. The globally adopted definition of these and the establishment of ways and procedures to develop them could lead to open-mindedness, passionate and hard-working teachers, ready to generate learning experiences that develop 21st century skills amongst their students, and face real problem-related situations (UNESCO, 2017).

The education stakeholders of the OECD are working in a new learning framework 2030 $(\mathrm{OECD}, 2018)$ to be plausible. In order to accomplish it, they are working in translating around 50 competences, which comprise almost all the ones mentioned in this study, into a set of specific constructs. In that way, teachers and school leaders could incorporate them into different curricula.

Linked to this, it is necessary to highlight that, on the one hand, there are some methodological active approaches appropriated to promote entrepreneurship as problembased learning, project-based learning and service-learning, together with design thinking and visual thinking techniques. On the other hand, it is important to consider that (inter) national IWL contribute to the development of competences and to reach more innovative results enriched by different ways of thinking, points of views and ways of doing things (Blankvoort et al., 2019; European Commission, 2020).

\section{Limitations}

Finally, we acknowledge the limitations of the study and recognise that perhaps the results of an international study could have allowed greater extrapolation. However, this was not the objective of the study, but rather to provide further insights into the characteristics of entrepreneurs and, specifically, of teacherpreneurs, as very few studies have been carried out to date (Keyhani and Kim, 2020).

\section{Future research}

Being witnessed that EE has seen exponential growth worldwide, mainly in business schools, the authors of this study are convinced that such growth will take place on primary teacher education level thanks to the policy recommendation pressure and actions of educational institutions all over the world, and also thanks to the research that is being done on this area, the results obtained and the plans developed.

We are also convinced that future empirical studies could delve into the role of in-service teacherpreneurs and analyse to what extent some characteristics identified in this study may be lacking in pre-service teacher education degrees and programmes. This could be crucial to the design of renewed updated curriculum according to the competences of the students of the 21 st century. This could also contribute to a better planning of initial and continuing education.

Finally, as Lackéus (2015, p. 7) indicated, although it is known that entrepreneurship should permeate into education and start at an early stage, there is still much to be done, and
Entrepreneur education for pre-service teachers 
"in practice however, explicit entrepreneurial activities on primary education levels are rare" (p. 7). This study aims to be an opportunity for primary education teachers to defend their right to quality training focussed on the skills that they must help to develop in their students, the great protagonists of a century marked by the challenges of a globalized and entrepreneurial society.

\section{References}

Aparicio, G., Iturralde, T. and Maseda, A. (2019), "Conceptual structure and perspectives on entrepreneurship education research: a bibliometric review", European Research on Management and Business Economics, Vol. 25 No. 3, pp. 105-113.

Arruti, A. and Paños-Castro, J. (2020), "How do future primary education student teachers assess their entrepreneurship competences? An analysis of their self-perceptions", Journal of Entrepreneurship Education, Vol. 23 No. 1, pp. 1-13.

Bacigalupo, M., Kampylis, P., Punie, Y. and Van den Brande, G. (2016), EntreComp: The Entrepreneurship Competence Framework, Publication Office of the European Union, Luxembourg.

Berry, B., Rasberry, M. and Williams, A. (2007), Recruiting and Retraining Quality Teachers for High Needs Schools: Insights from NBTS Summits and Others Policy Initiatives, Center for Teaching Quality, Carrboro.

Bisquerra, R. (2009), Metodología de la investigación educativa, Editorial La Muralla, Madrid.

Blankvoort, N., Kaelin, V.C., Poerbodipoero, S. and Guidetti, S. (2019), "Higher education students' experiences of a short-term international programme: exploring cultural competency and professional development”, Educational Research, Vol. 61 No. 3, pp. 356-370.

Blass, E. (2018), "Developing a curriculum for aspiring entrepreneurs: what do they really need to learn?”, Journal of Entrepreneurship Education, Vol. 21 No. 4, pp. 1-14.

Boldureanu, G., Ionescu, A.M. and Bercu, A.M. (2020), "Entrepreneurship education through successful entrepreneurial models in higher education institutions", Sustainability, Vol. 12 No. 3, pp. 1-33.

Bridge, S. (2017), “Is 'entrepreneurship' the problem in entrepreneurship education?”, Education + Training, Vol. 59 Nos 7-8, pp. 740-750.

Bucardo, A., Saavedra, M.L.Y and Camarena, M.E. (2015), "Hacia una comprensión de los conceptos de emprendedores y empresarios”, Suma de Negocios, Vol. 6 No. 13, pp. 98-107.

Coduras, A., Levie, J., Kelley, D.J., Sæmundsson, R.J. and Schøtt, T. (2010), "Global entrepreneurship monitor special report: a global perspective on entrepreneurship education and training", available at: http://entreprenorskapsforum.se/wp-content/uploads/2010/05/GEM-Special_ report_entrepreneurship-training.pdf (accessed 13 April 2020).

Coduras, A., Saiz-Alvarez, J.M. and Ruiz, J. (2016), "Measuring readiness for entrepreneurship: an information tool proposal", Journal of Innovation and Knowledge, Vol. 1 No. 2, pp. 99-108.

Comisión Europea (2008), La iniciativa emprendedora en la enseñanza superior, especialmente en estudios no empresariales, Comisión Europea, Bruselas.

Comisión Europea (2013), Plan de acción sobre emprendimiento 2020. Relanzar el espiritu emprendedor en Europa, Comisión Europea, Bruselas.

Comisión Europea (2014), Educación en emprendimiento, Guía del educadorUnidad «Emprendimiento 2020», Bruselas.

Commission of the European Communities (2003), Green Paper Entrepreneurship in Europe, Comisión Europea, Bruselas.

Council of the European Union (2015), "Council conclusions on entrepreneurship in education and training", Official Journal of the European Union, available at: https://eur-lex.europa.eu/legalcontent/EN/TXT/PDF/?uri=CELEX:52015XG0120(01)\&from=ES (accessed 14 July 2020). 
de Pablo Valenciano, J., Uribe-Toril, J. and Ruiz-Real, J.L. (2019), "Entrepreneurship and education in the 21st century: analysis and trends in research", Journal of Entrepreneurship Education, Vol. 22 No. 4, pp. 1-20.

European Commission (2020), Erasmus+. Programme Guide, European Commission, Brussels.

European Commission/EACEA/Eurydice (2016), Entrepreneurship Education at School in EuropeEurydice Report, Publications Office of the European Union, Luxembourg.

Ferreiro, R.F. (2011), "Tres vértices del triángulo de las competencias didácticas: teoría, metodología y método", Revista Complutense de Educación, Vol. 22 No. 1, pp. 11-23.

Galvão, A., Ferreira, J.J. and Marques, C. (2018), "Entrepreneurship education and training as facilitators of regional development: a systematic literature review", Journal of Small Business and Enterprise Development, Vol. 25 No. 1, pp. 17-40.

Gibb, A., Haskins, G. and Robertson, I. (2013), "Leading the entrepreneurial university. Meeting the entrepreneurial development needs of higher education institutions", in Altmann, A. and Ebersberger, B. (Eds), Universities in Change, Springer, New York, NY, pp. 9-45.

GómezLlanos, L.M., Hernández, T., Mejía, D., Heilbron, J., Martín, J., Mendoza, J. and Senior, D. (2017), "Competencias emprendedoras en básica primaria: hacia una educación para el emprendimiento", Pensamiento and Gestión, Vol. 43, pp. 150-188.

Hameed, I. and Irfan, Z. (2019), "Entrepreneurship education: a review of challenges, characteristics and opportunities", Entrepreneurship Education, Vol. 2 Nos 3-4, pp. 135-148.

Hattie, J. (2003), Teachers Make a Difference: What Is the Research Evidence?, Australian Council for Educational Research, Camberwell.

Henry, C. and Lewis, K. (2018), "A review of entrepreneurship education research", Education + Training, Vol. 60 No. 3, pp. 263-286.

Isa, A.S. (2019), "Teachers' perception on the significance of entrepreneurship educational as a tool for youth empowerment”, International Journal of Scientific Research in Multidisciplinary Studies, Vol. 5 No. 12, pp. 66-73.

Keyhani, N. and Kim, M.S. (2020), "A systematic literature review of teacher entrepreneurship", Entrepreneurship Education and Pedagogy, pp. 1-20.

Lackéus, M. (2015), Entrepreneurship in Education, what, Why, when, How, OECD and European Commission, Paris.

Linton, G. and Klinton, M. (2019), "University entrepreneurship education: a design thinking approach to learning", Journal of Innovation and Entrepreneurship, Vol. 8 No. 3, pp. 1-11.

López, J., Pozo, S., Arturo, A. and Rodríguez-García, A.M. (2019), "Análisis del desempeño docente en la educación para el emprendimiento en un contexto español”, Aula Abierta, Vol. 48 No. 3, pp. 321-330.

Neck, H.M. and Greene, P.G. (2011), "Entrepreneurship education: known worlds and new frontiers", Journal of Small Business Management, Vol. 49 No. 1, pp. 55-70.

Núñez, L. and Núñez, M. (2016), "Noción de emprendimiento para una formación escolar en competencia emprendedora”, Revista Latina de Comunicación Social, Vol. 71, pp. 1069-1089.

OECD (2018), The Future of Education and Skills. Education 2030, available at: https://www.oecd.org/ education/2030/E2030\%20Position\%20Paper\%20(05.04.2018).pdf (accessed 14 July 2020).

Othman, N.H. and Othman, N. (2019), "A systematic review on entrepreneurship education in higher learning institutions in Southeast Asia”, Universal Journal of Educational Research, Vol. 7 No. 11, pp. 2406-2416.

Paiva, T., Alves, M.L. and Sampaio, J.H. (2019), "Entrepreneurship education: background and future”, in Cagica, L. and Dias, A. (Eds), Global Considerations in Entrepreneurship Education and Training, IGI Global, Pennsylvania, pp. 151-161.

Ragil, I., Sajidan, W. and Ashadi (2019), "Improving the entrepreneurship competence of pre-service elementary teachers on professional education program through the skills of disruptive innovators", Elementary Education Online, Vol. 18 No. 3, pp. 1186-1194.
Entrepreneur education for pre-service teachers 
ET

$62,7 / 8$

840

Raine, A.L. and Pandya, M. (2019), "Three keys to entrepreneurial success: curiosity, creativity, and commitment", Entrepreneurship Education, Vol. 2 Nos 3-4, pp. 189-198.

Rasmussen, A. and Nybye, N. (2013), Entrepreneurship Education: Progression Model, The Danish Foundation for Entrepreneurship - Young Enterprise, Odense C, Denmark, available at: https:// www.ffe-ye.dk/media/44723/Progression-model-English.pdf (accessed 14 July 2020).

Rodríguez, G. (2016), "Educación informal en emprendimiento y creatividad en escuelas innovadoras", Opción, Vol. 32 No. 12, pp. 425-443.

Rodríguez-Martínez, C. and Díez, E.J. (2014), "Conocimiento y competencias básicas en la formación inicial de maestras y maestros", Profesorado. Revista de currículum y formación del profesorado, Vol. 18 No. 1, pp. 383-396.

Ruiz, M.C., De Hoyos-Ruperto, M., Pomales-García, C. and Amador-Dumois, M.A. (2019), Entrepreneurial Education Program for STEM Teachers and Students, ASEE Southeastern Section Conference, American Society for Engineering Education.

Sadewo, Y.D. (2020), The Effect of Learning Outcomes in Entrepreneurship Education Programs of Interest in Entrepreneurship, paper presented at 3rd International Conference on Economics Education and Entrepreneurship, August 29-31, Batam, Indonesia, available at: https:/osf.io/ m29x8/ (accessed 13 April 2020).

Sam, C. and van der Sijde, P. (2014), "Understanding the concept of the entrepreneurial university from the perspective of higher education models", Higher Education, Vol. 68 No. 6, pp. 891-908.

San-Martín, P., Fernandez-Laviada, A. and Pérez, A. (2020), "La importancia de la educación empresarial y su terminología”, Small Business International Review, Vol. 4 No. 1, pp. 69-87.

Saraiva, H. and Paiva, T. (2020), "Entrepreneurship education: background and future”, in Leitão, J.G. and Cagica, L. (Eds), Handbook of Research on Approaches to Alternative Entrepreneurship Opportunities, IGI Globa, Pennsylvania, pp. 1-12.

Suska, M. (2018), "Entrepreneurial studies in higher education: some insights for entrepreneurship education in Europe", Horyzonty Polityki, Vol. 9 No. 29, pp. 143-156.

Syae, P. (2020), "The cultivation of entrepreneurship values among students of senior high school in Jakarta DKI", Practitioner Research, Vol. 1, pp. 199-211.

Taatila, V.P. (2010), "Learning entrepreneurship in higher education”, Education + Training, Vol. 52 No. 1, pp. 48-61.

The European Parliament and the Council of the European Union (2006), Recommendation of the European Parliament and of the Council on Key Competences for Lifelong Learning, Official Journal of the European Union, Luxembourg.

UNESCO (2017), Education and Skills for the 21st Century, Working paper, p. E2030, available at: http://www.unesco.org/new/fileadmin/MULTIMEDIA/FIELD/Santiago/pdf/Habilidades-SXXIBuenos-Aires-Eng.pdf (accessed 14 July 2020).

Von Graevenitz, G., Harhoff, D. and Weber, R. (2010), "The effects of entrepreneurship education”, Journal of Economic Behavior and Organization, Vol. 76 No. 1, pp. 90-112.

Welsh, D.H.B., Tullar, W.L. and Nemati, H. (2016), "Entrepreneurship education: process, method, or both?", Journal of Innovation and Knowledge, Vol. 1 No. 3, pp. 125-132.

Wibowo, A., Saptono, A. and Suparno, S. (2018), "Does teachers' creativity impact on vocational students' entrepreneurial intention?", Journal of Entrepreneurship Education, Vol. 21 No. 3, pp. 1-12.

Yomi-Akinola, O.G. and Adedapo, A.A. (2019), "Imperative of entrepreneurship education for university students: the case study of University of Ibadan”, UNILAG Journal of Humanities (UJH), Vol. 7 No. 1, pp. 34-45.

Zangeneh, H., Kavousi, A. and Bahrami, Z. (2020), "Teachers' attitudes toward teaching-learning methods of entrepreneurship education in elementary education", Education Strategies in Medical Sciences (ESMS), Vol. 12 No. 6, pp. 1-7. 
Zhao, J. (2019), "Combination of Innovation education and professional education in colleges and universities", paper presented at 3rd International Conferene on Economic, Management and Education Technology (ICEMEET 2019), May 18-19, 2019, Suzhou, available at: https:// webofproceedings.org/proceedings_series/ESSP/ICEMEET\%202019/ICEMEET19280.pdf (accessed 13 April 2020).

Entrepreneur education for pre-service teachers

Corresponding author

Arantza Arruti can be contacted at: aarruti@deusto.es

For instructions on how to order reprints of this article, please visit our website:

www.emeraldgrouppublishing.com/licensing/reprints.htm

Or contact us for further details: permissions@emeraldinsight.com 